\section{Temporal variation in relative zircon abundance throughout Earth history}

\section{C.B. Keller ${ }^{1,2,3^{*}}$, P. Boehnke ${ }^{4,5}$, B. Schoene ${ }^{3}$}

OPEN 2 Access

\section{Abstract}

doi: 10.7185/geochemlet.1721

Zircon is the preeminent chronometer of deep time on Earth, informing models of crustal growth and providing our only direct window into the Hadean Eon. However, the quantity of zircon crystallised per unit mass of magma is highly variable, complicating interpretation of the terrestrial zircon record. Here we combine zircon saturation simulations with a dataset of $\sim 52,000$ igneous whole rock geochemical analyses to quantify secular variation in relative zircon abundance throughout Earth history. We find dramatically increasing zircon abundance per mass of magma through geologic time, suggesting that the zircon record underestimates past crustal volume even if preservation bias is eliminated. Similarly, zircons were even less likely to crystallise from low-silica mas in we ey volume of generally felsic Hadean crust than previously expected.

Received 8 November 2016 | Accepted 20 March 2017 | Published 20 April 2017

\section{Letter}

The accessory mineral zircon is ubiquitous, refractory, and readily radiometrically dated to high precision and accuracy through the U and Th decay systems. This trinity of properties has made zircon into a standard mineral tracer of geologic time, resolving timescales from Gyr to kyr through the related $\mathrm{U}-\mathrm{Th} / \mathrm{Pb}$ and U-series geochronometers (e.g., Schmitt, 2011; Schoene, 2014). Zircons constitute the oldest known terrestrial material, providing a glimpse of Earth in the Hadean Eon which has been argued to reveal a remarkably modern environment, complete with liquid water (Mojzsis et al., 2001; Wilde et al., 2001) and felsic crust (Harrison, 2009). Given its ubiquity in igneous rocks, zircon has been used as a proxy for

1. Berkeley Geochronology Center, Berkeley, CA 94709, USA

2. Department of Earth and Planetary Science, University of California, Berkeley, CA 94720, USA

3. Department of Geosciences, Guyot Hall, Princeton University, Princeton, NJ 08544-1042, USA

Corresponding author (cbkeller@berkeley.edu)

4. Chicago Center for Cosmochemistry, The University of Chicago, Chicago, IL 60637, USA

5. Department of the Geophysical Sciences, The University of Chicago, Chicago, IL 60637, USA

magma crystallisation, crust production, and even crustal composition (Condie $e$ t al., 2009; Cawood et al., 2013; Parman, 2015; Lee et al., 2016). However, quantity of zircon is not a direct substitute for quantity of magma or crust. Instead, zircon abundance in the igneous record is a function of magma composition, which is both spatially and temporally heterogeneous. Moreover, due to the high closure temperatures of the U-Th/Pb and U-series systems, ages from these geochronometers exclusively date zircon crystallisation (Schoene, 2014), which need not coincide with the crystallisation of other silicate minerals.

The temperature $T_{\text {sat }}$ at which zircon saturates in an igneous magma can be accurately predicted by an empirical equation of the form

$$
\frac{a}{T_{\text {sat }}}=\ln \left(\frac{[\mathrm{Zr}]_{\text {zircon }}}{[\mathrm{Zr}]_{\text {melt }}}\right)+b M+c
$$

where $a, b$, and $c$ are constants, $[\mathrm{Zr}]$ is zirconium concentration, and $M$ is a compositional measure of magma polymerisation defined on a molar basis as

$$
M=\frac{[\mathrm{Na}]+[\mathrm{K}]+2[\mathrm{Ca}]}{[\mathrm{Al}] *[\mathrm{Si}]}
$$

(Watson and Harrison, 1983; Boehnke et al., 2013). Purely stochastic heterogeneity in magma composition would produce no meaningful temporal variation in zircon saturation behaviour. However, on sufficiently long geologic timescales, decreasing mantle potential temperature from the early Earth to the present is reflected in systematic variations in average magma composition, including increasing abundance of incompatible elements such as Zr (Keller and Schoene, 2012)

Even within a closed system, magma composition (including $M$ and $[\mathrm{Zr}]_{\text {melt }}$ ) varies systematically throughout crystallisation as a function of pressure, temperature, and melt fraction, such that a single bulk zircon saturation temperature is insufficient to characterise the zircon saturation behaviour of simple igneous systems (e.g., Harrison et al., 2007). Accordingly, in order to examine the effects of temporal variations in magma composition throughout Earth history on zircon saturation behaviour, we combine zircon saturation calculations with alphaMELTS (Ghiorso et al., 2002; Smith and Asimow, 2005) major element simulations on 52,300 whole rock compositions spanning the preserved rock record from modern to Archean. While generally incompatible in silicate minerals, zirconium mineral/melt partition coefficients vary widely between common silicate minerals and may be as high as $0.3-0.5$ for clinopyroxene, amphibole, and garnet. Consequently, to ensure accurate zircon saturation calculations, mineralspecific partition coefficients from the Geochemical Earth Reference Model database (GERM, 2013) were used when calculating melt Zr concentrations at each temperature step of each alphaMELTS simulation. Finally, to obtain temporal trends, the results of zircon saturation simulations were subjected to weighted bootstrap re-sampling following the approach of Keller and Schoene (2012), to 
calculate accurate estimates of the mean and standard error of the mean for each independent variable of interest.

The primary forcings on zircon abundance over Gyr timescales are illus trated in Figure 1a as averages for igneous whole rock samples preserved in the present-day continental crust. Over the past $4 \mathrm{Gyr}$, average igneous zirconium content has increased, while average $M$-value has decreased. These changes are a consequence of secular mantle cooling, where lower average mantle melting extent has led to increased average concentrations of incompatible elements such as $\mathrm{Zr}$ (Keller and Schoene, 2012), and generally lower $M$ values due to lower $\mathrm{Ca}$ and higher $\mathrm{Al}$ abundance. Combined, these forcings should result in substantially increased zircon concentration in the igneous record (mass of zircon crystallised per mass of magma) since the early Archean.

While zircon saturation is largely independent of magma pressure and water content (Boehnke et al.,2013), the crystallisation of other silicate minerals is not, with higher pressure and lower water content generally increasing crystallisation temperatures. Consequently, in drier or deeper magmas, most silicate minerals will crystallise early relative to zircon (Keller et al., 2015); such magmas will be more likely to crystallise fully to the solidus without ever reaching zircon saturation. Correspondingly, saturation simulations run at higher pressures or lower magma water contents display lower total zircon abundance at any given time, as shown in Figure 1b. Nonetheless, common temporal trends are revealed across a wide range of $\mathrm{P}$ and $\mathrm{H}_{2} \mathrm{O}$ values, with the mass of zircon saturated per mass of magma increasing substantially since the early Archean (Fig. 1b). The influence of crystallisation pressure and magma water content on final whole rock zircon limits our ability to reconstruct unambiguously past magma volumes from the zircon record. However, proposed scenarios of constant or decreasing crusta thickness (e.g., Keller and Schoene, 2012) and constant or increasing magma wate content from the Archean to the present would, if anything, accentuate the trends observed in Figure 1.

Changing average zirconium concentration and $M$ value over the past $\sim 4$ Gyr have additional consequences for the position of zircon in the magma crystallisation sequence. In general, mafic magmas require greater extents of in situ differentiation to reach zircon saturation, and thus crystallise zircon at lower residual melt fractions (Fig. 1c). As observed in Figure 1c, zircon saturation in Archean magmas of any given silica range is further delayed and diminished due to lower average $[\mathrm{Zr}]$ and higher $M$-values. Unsurprisingly, delayed zircon saturation is directly correlated with lower total zircon mass saturated (Fig. 1c), an effect that is accentuated if a magma is not allowed to cool fully to its solidus, either due to eruptive quenching or residual melt extraction.

Due to non-Newtonian magma rheology, magmas containing less than $\sim 37 \%$ melt are disproportionately unlikely to erupt (Caricchi et al., 2007), common volcanic rocks are typically well above this threshold. As residual melt is largely quenched to an amorphous glass upon eruption, any mineral phases crystallising below the eruptive melt fraction will be absent from the volcanic
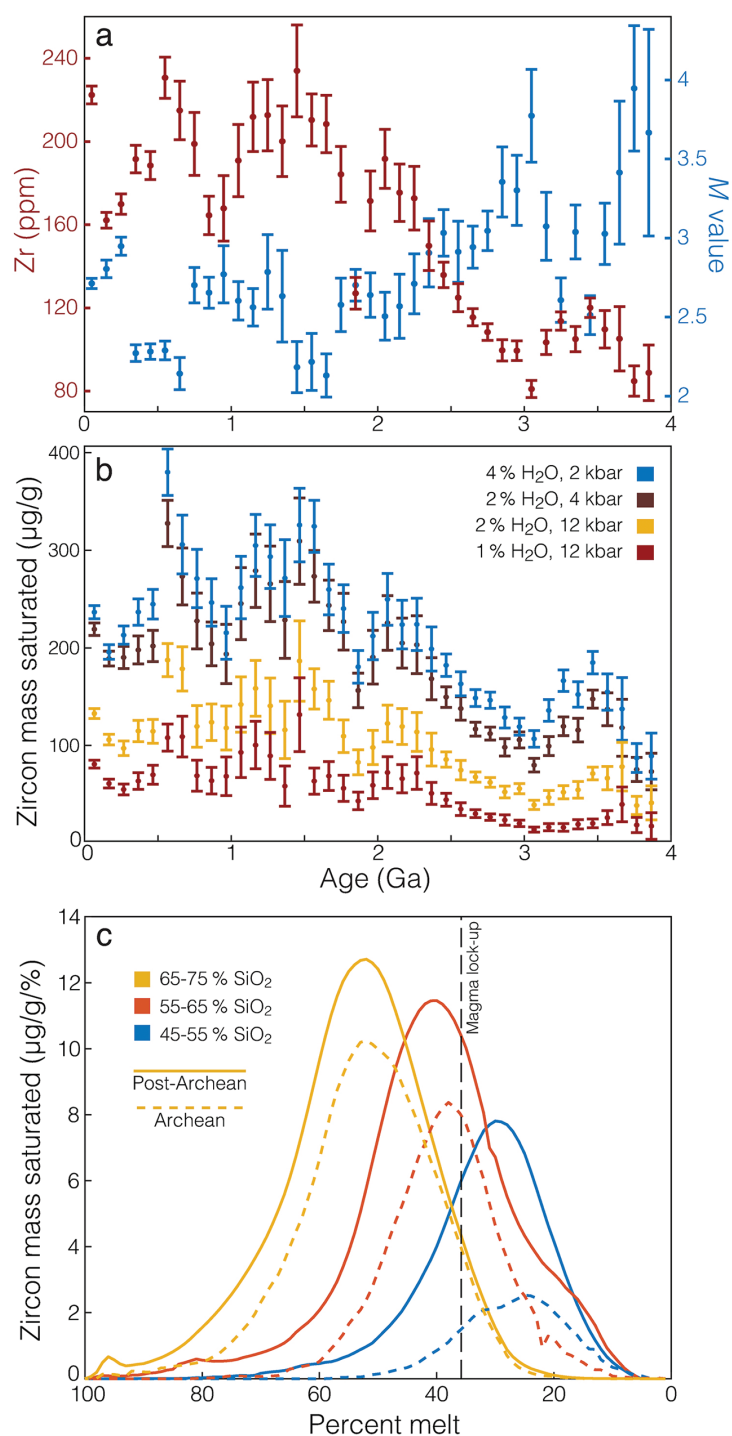

Figure 1 (a) Average zirconium and $M$ value throughout the preserved rock record for continental igneous rocks with $40-80 \% \mathrm{SiO}_{2}$. (b) Calculated average zircon concentration (micrograms of zircon per gram of whole rock) as a function of time, under a range of possible crystallisation conditions. (c) Zircon saturation distributions during magma crystallisation as a function of percent melt for varying silica ranges, calculated at 6 kilobar and 3 wt. $\% \mathrm{H}_{2} \mathrm{O}$. Relative zircon abundance is reported as micrograms of zircon saturated per gram of magma per percentage-point decrease in residual melt fraction. All uncertainties are two standard error of the mean. 
record. Given that basalts display the greatest delay in zircon saturation and are substantially over-represented in the volcanic record (Keller et al., 2015), the effect of eruptive quenching on zircon saturation will be most noticeable in the mafic record. Phanerozoic basalts typically erupt with fewer than $30 \%$ phenocrysts by volume (e.g., Bryan, 1983), and at the time of eruption contain little or no zircon, as expected from Figure 1c. Delayed zircon saturation in Archean lithologies should result in an even more pronounced dearth of zircons in the Archean volcanic record for magmas of any given silica content consistent with the observations in Eoarchean volcaniclastic metasediments, e.g., Kamber et al. (2005).

As shown in Figure 2a, Archean mafic magmas saturated on average very little zircon per mass of whole rock both relative to either Archean felsic rocks or post-Archean mafic rocks when crystallised to their solidus at a given set of $\mathrm{P}$ $\mathrm{H}_{2} \mathrm{O}$ conditions. This dramatic deficit is equivalent to a difference of more than $10 \mathrm{wt}$ \% silica in whole rock composition, such that for example, an Archean granodiorite with $65 \mathrm{wt}$. \% $\mathrm{SiO}_{2}$ saturates only as much zircon as a Phanerozoic basalt with 53 wt. \% $\mathrm{SiO}_{2}$ (Fig. 2b).

Moreover, while felsic magmas in Figure 2a consistently saturate more zircon on average than their mafic counterparts at all times in Earth history, this relative imbalance was stronger in the Archean. Figure $2 \mathrm{c}$ illustrates the calculated average mass of zircon saturated during complete crystallisation of a given mass of mafic magma $\left(43-53 \% \mathrm{SiO}_{2}\right)$ relative to that saturated in an equal mass of coeval felsic magma $\left(63-73 \% \mathrm{SiO}_{2}\right)$. As observed in Figure $2 \mathrm{c}$, the discrepancy between mafic and felsic zircon abundance is roughly three times greater in the Archean, with Archean mafic magmas crystallising on average little more than a tenth of the zircon mass saturated by an equal mass of coeval felsic magma when both are fully crystallised. This inequality between Archean mafic and felsic zircon abundance is exacerbated when considering magmas that do not fully crystallise, due to the greatly delayed zircon saturation of Archean mafic magmas (Fig. 1c) - an effect that would be further compounded by the apparent prevalence of volcanic lithologies in the Archean mafic record (e.g., de Wit and Ashwal, 1997).

If not accounted for, systematic temporal variations in relative zircon abundance would lead to substantial underestimation of the amount of crust required to produce Earth's early zircon record. The impact of this trend on preserved zircon age spectra is shown in Figure 3a, which illustrates how the zircon age spectrum of Voice et al. (2011) would differ if magmas throughout Earth history had crystallised zircon at present-day rates, for a range of assumed model conditions. For magmas crystallising at a given set of $\mathrm{P}, \mathrm{H}_{2} \mathrm{O}$ conditions, this result is equivalent to the true magma age spectrum required to produce the observed detrital zircon age spectrum in the absence of preservation bias - with true average crystallisation conditions likely intermediate between the shallow/wet and deep/dry endmembers shown in Figure 3a. As peaks in global zircon age spectra are often interpreted as times of increased global magmatic activity,
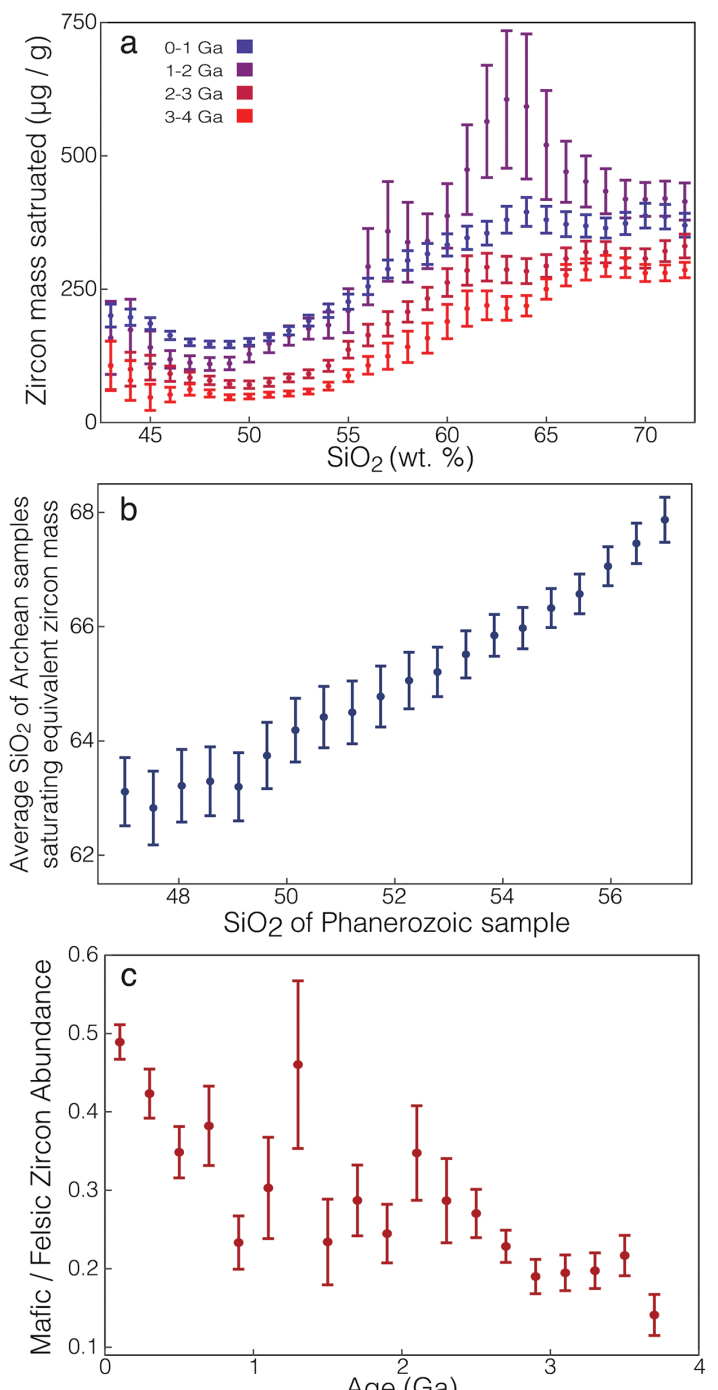

$\operatorname{Age}^{2}(\mathrm{Ga})$

Figure 2 Temporal variability in the distribution of zircon between igneous rocks of different silica contents, calculated at 6 kilobar and $3 \mathrm{wt}$. $\% \mathrm{H}_{2} \mathrm{O}$. (a) Temporal variation in relative zircon abundance as a function of silica. (b) Line of silica equivalence between Archean and Phanerozoic samples (the silica contents required to saturate the same mass of zircon in Archean and Phanerozoic magmas). (c) The mass of zircon saturated per mass of mafic magma $\left(43-53 \% \mathrm{SiO}_{2}\right.$ ) relative to that saturated in an equivalent mass of coeval felsic magma $\left(63-73 \% \mathrm{SiO}_{2}\right)$. The likelihood of saturating zircon in mafic lithologies was dramatically lower (by a factor of nearly 5) in the earliest Archean than it is today. All uncertainties are two standard error of the mean. 

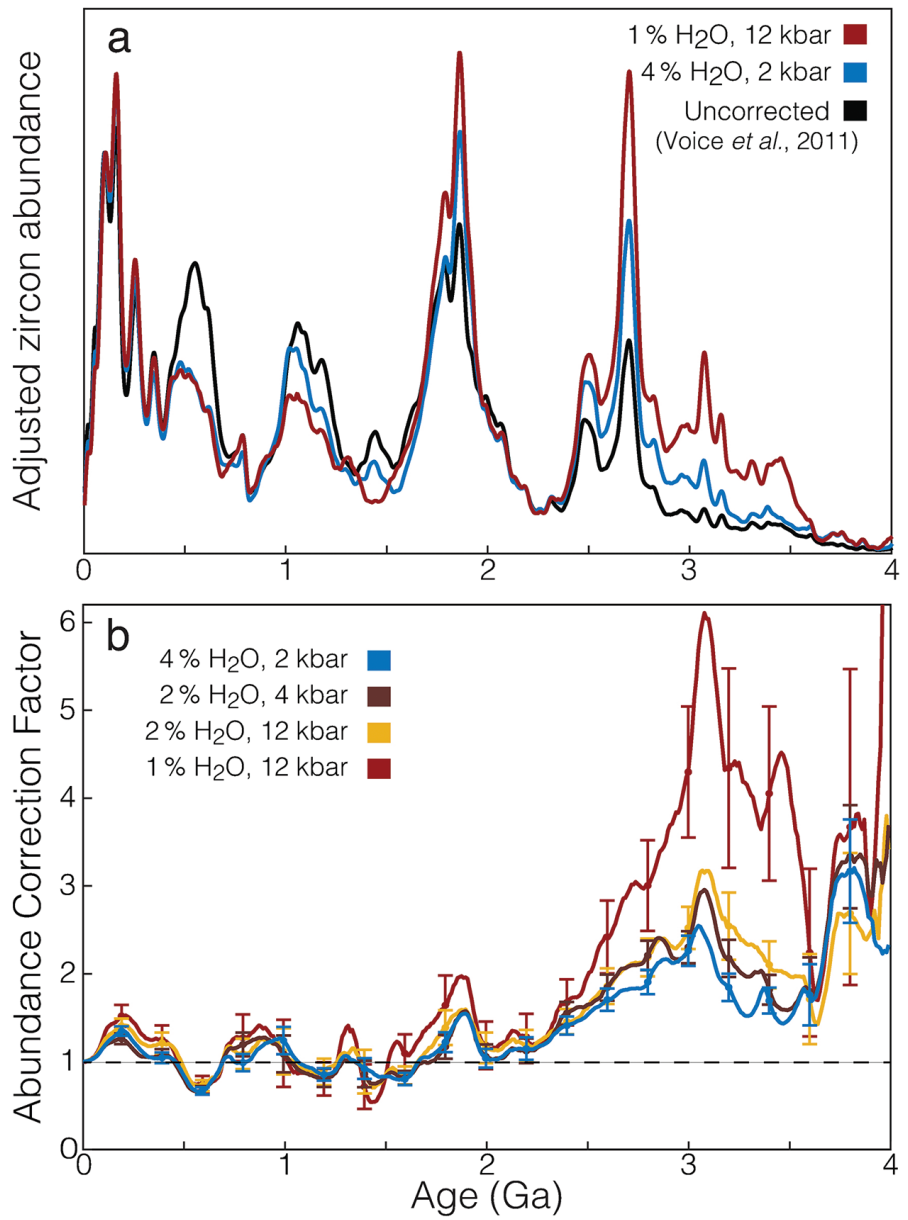

Figure 3 (a) The effect of applying a relative zircon abundance correction (normalising to constant magma zircon productivity) to the detrital zircon age spectrum of Voice et al. (2011) for varying crystallisation conditions. (b) The average mass of magma throughout Earth history required to produce the same mass of zircon as a unit mass of average present-day magma.

correlated with the plate tectonic Wilson cycle (e.g., Condie and Aster, 2010), the corrected age spectrum may imply a more steady-state supercontinent cycle with similar maxima in magmatic activity to $\sim 3 \mathrm{Ga}$, or (depending on the strength of preservation bias) even before.
The zircon abundance correction increases the magmatic significance of the Archean and Proterozoic zircon record, and appears to improve the correspondence in magnitude between temporally correlated zircon abundance maxima and mantle depletion events (e.g., Pearson et al., 2007). Considering present-day zircon productivity levels, three to five times more Archean magma was required to produce a given amount of zircon (Fig. $3 b$ ); such corrections should be applied to models relying on zircon abundance as a proxy for crust or magma extent.

If Hadean mantle potential temperatures were equal to or greater than those of the early Archean, we might infer that zircon saturation was inhibited in Hadean mafic magmas by a factor equal to or greater than that of the early Archean. This would decrease the likelihood that any given Hadean zircon originated from a mafic lithology by more than a factor of three relative to an equivalent model where systematic temporal trends in whole rock geochemistry are neglected.

While the above considerations are applicable in principle to zircon-based crustal growth models such as those of Belousova et al. (2010) or Dhuime et al. (2012), a simple correction factor as in Figure 3b alone is likely insufficient. Firstly, applying the models of Figure 3 to a crustal growth curve assumes closed system crystallisation at crustal scale. While this may seem a minor assumption, it does not necessarily hold in the early Hadean: a terrestrial flotation cumulate, for instance, would systematically exclude dense zircon. Consistent with this expectation, lunar anorthosites contain only $0.1-0.5$ ppm zirconium (e.g., several hundred times lower than an average Archean basalt), offset by zirconium enrichments up to 2000 ppm in complementary KREEP basalts (Ehmann et al., 1979). Such extreme zirconium deficiency in Lunar anorthosites indicates that the most likely candidate lithology for primordial terrestrial crust is effectively invisible to zircon-based crustal growth models. Secondly, the insensitivity of zircon saturation to water content along with $\mathrm{Zr}$ immobility in aqueous fluids implies that most subducted zircon will not return to the crust in new arc magmas-a corollary to the well-known arc signature of high field-strength element depletion. Consequently, while zircon-based crustal growth models account for crustal magmatic reworking, crustal destruction by sediment subduction and subduction-erosion will be largely undetectable in the zircon record. Together, these specific issues arising from the crystallisation and stability of zircon suggest that both initial crustal volume and subsequent net growth or destruction rate are poorly bounded and subject to assumptions (e.g., Fig. S-4)

Together, our results emphasise the significance of the extant zircon record of early Earth history, given the difficulty of saturating zircon under early Earth conditions due to lower average magma zirconium content and lower silicate magma polymerisation state. Under such conditions, zircon saturation is delayed and diminished, especially in mafic lithologies. Consequently, more crust is required to explain preserved zircon age spectra, and a potentially significant volume of felsic crust is favoured as the likely source of preserved Hadean zircons. 


\section{Acknowledgements}

C.B.K. was supported in part by the Department of Energy Computational Science Graduate Fellowship Program of the Office of Science and National Nuclear Security Administration in the Department of Energy under contract DE-FG02-97ER25308. Computational resources were provided by the Princeton Institute for Computational Science and Engineering.

Editor: Graham Pearson

\section{Author Contributions}

C.B.K. conducted the calculations and prepared the manuscript. All authors contributed to the design of the study and the interpretation of the results.

\section{Data Availability}

All data and source code used in this study are freely available at https:/github. com/brenhinkeller/meltstzirc.

\section{Additional Information}

Supplementary Information accompanies this letter at www.geochemicalperspectivesletters.org/article1721

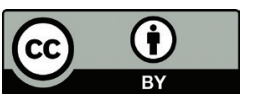

This work is distributed under the Creative Commons Attribution 4.0 License, which permits unrestricted use, distribution, and reproduction in any medium, provided the original author and source are credited. Additional information is available at http://www. geochemicalperspectivesletters.org/copyright-and-permissions.

Cite this letter as: Keller, C.B., Boehnke, P., Schoene, B. (2017) Temporal variation in relative zircon abundance throughout Earth history. Geochem. Persp. Let. 3, 179-189.

\section{References}

Belousova, E., Kostitsyn, Y., Griffin, W.L., BegG, G.C., O'Reilly, S.Y., Pearson, N.J. (2010) The growth of the continental crust: Constraints from zircon Hf-isotope data. LITHOS 119, 457-466.

BoehnKe, P., Watson, E.B., TRAil, D., HarRison, T.M., SChmitt, A.K. (2013) Zircon saturation re-revisited Chemical Geology 351, 324-334.
BRYAN, W.B. (1983) Systematics of modal phenocryst assemblages in submarine basalts: Petrologic implications. Contributions to Mineralogy and Petrology 83, 62-74.

CARICCHI, L., BuRLINI, L., UlmeR, P., GERYA, T. (2007) Non-Newtonian rheology of crystal-bearing magmas and implications for magma ascent dynamics. Earth and Planetary Science Letters 264, 402-419.

CAWOOD, P.A., HAWKeSWORTH, C.J., DHuime, B. (2013) The continental record and the generation of continental crust. Geological Society of America Bulletin 125, 14-32.

CONDIE, K.C., AsteR, R.C. (2010) Episodic zircon age spectra of orogenic granitoids: The supercontinent connection and continental growth. Precambrian Research 180, 227-236.

Condie, K.C., Belousova, E., Griffin, W.L., SiRCombe, K.N. (2009) Granitoid events in space and time: Constraints from igneous and detrital zircon age spectra. Gondwana Research 15, 228-242.

DE WIT, M.J., AshWAL, L.D. (1997) Greenstone belts. Oxford University Press, Oxford.

Dhuime, B., Hawkesworth, C.J., CAwood, P.A., Storey, C.D. (2012) A Change in the Geodynamics of Continental Growth 3 Billion Years Ago. Science 335, 1334-1336.

EhmanN, W.D., ChYI, L.L., GarG, A.N., Ali, M.Z. (1979) The distribution of zirconium and hafnium in terrestrial rocks, meteorites and the moon. Physics and Chemistry of the Earth 11 $247-259$.

GERM (2013) Geochemical Earth Reference Model Partition Coefficient Database. http://www. earthref.org/KDD/

Ghiorso, M.S., Hirschmann, M.M., Reiners, P.W., Kress, V.C.III (2002) The pMeltS: A revision of MELTS for improved calculation of phase relations and major element partitioning related to partial melting of the mantle to 3 GPa. Geochemistry Geophysics Geosystems 3, 1-36.

HARRISON, T.M. (2009) The Hadean Crust: Evidence from i4 Ga Zircons. Annual Review of Earth and Planetary Sciences 37, 479-505.

HARRISON, T.M., WATSON, E.B., AIKMAN, A.B. (2007) Temperature spectra of zircon crystallization in plutonic rocks. Geology 35, 635-638.

Kamber, B.S., Whitehouse, M., Bolhar, R., Moorbath, S. (2005) Volcanic resurfacing and the early terrestrial crust: Zircon U-Pb and REE constraints from the Isua Greenstone Belt southern West Greenland. Earth and Planetary Science Letters 240, 276-290.

KelLer, C.B., Schoene, B. (2012) Statistical geochemistry reveals disruption in secular lithospheric evolution about 2.5 Gyr ago. Nature 485, 490-493.

Keller, C.B., Schoene, B., Barboni, M., Samperton, K.M., Husson, J.M. (2015) Volcanicplutonic parity and the differentiation of the continental crust. Nature 523, 301-307.

LeE, C.-T.A., Yeung, L.Y., McKenzie, N.R., YoKoyama, Y., OZaKi, K., Lenardic, A. (2016) Twostep rise of atmospheric oxygen linked to the growth of continents. Nature Geoscience 9, 417-424.

Mojzsis, S.J., HARRISON, T.M., Pidgeon, R.T. (2001) Oxygen-isotope evidence from ancient zircons for liquid water at the Earth's surface 4,300 Myr ago. Nature 409, 178-181

PARMAN, S.W. (2015) Time-lapse zirconography: Imaging punctuated continental evolution. Geochemical Perspectives Letters 1, 43-52.

Pearson, D.G., Parman, S.W., Nowell, G.M. (2007) A link between large mantle melting events and continent growth seen in osmium isotopes. Nature 449, 202-205.

SCHMITT, A.K. (2011) Uranium Series Accessory Crystal Dating of Magmatic Processes. Annual Review of Earth and Planetary Sciences 39, 321-349.

SCHOENE, B. (2014) 4.10 U-Th-Pb Geochronology. In: Rudnick, R.L. (Ed.) Treatise on Geochemistry Volume 4: The Crust. Second Edition, Elsevier, Amsterdam, 341-378.

SMith, P.M., Asimow, P.D. (2005) Adiabat 1ph: A new public front-end to the MELTS, pMELTS, and pHMELTS models. Geochemistry Geophysics Geosystems 6, 1-8. 
Voice, P.J., KowalewsKi, M., EriKsson, K.A. (2011) Quantifying the Timing and Rate of Crustal Evolution: Global Compilation of Radiometrically Dated Detrital Zircon Grains. The Journal of Geology 119, 109-126.

WATSON, E.B., HARRISON, T.M. (1983) Zircon saturation revisited: temperature and composition effects in a variety of crustal magma types. Earth and Planetary Science Letters 64, 295-304.

Wilde, S.A., Valley, J.W., Peck, W.H., Graham, C.M. (2001) Evidence from detrital zircons for the existence of continental crust and oceans on the Earth 4.4 Gyr ago. Nature 409, 175-178. 